\title{
Risk Mutualization in Central Clearing: An Answer to the Cross-Guarantee Phenomenon from the Financial Stability Viewpoint
}

\author{
Melinda Friesz ${ }^{1}$, Kira Muratov-Szabó ${ }^{2}$, Andrea Prepuk ${ }^{3}$ and Kata Váradi ${ }^{4, * \mathbb{D}}$ \\ 1 KELER Ltd., 1074 Budapest, Hungary; szodorai.melinda@keler.hu \\ 2 KELER CCP Ltd., 1074 Budapest, Hungary; muratov-szabo.kira@kelerkszf.hu \\ 3 MVM CEEnergy Ltd., 1138 Budapest, Hungary; prepuka@ceenergy.hu \\ 4 Department of Finance, Corvinus University of Budapest, 1093 Budapest, Hungary \\ * Correspondence: kata.varadi@uni-corvinus.hu
}

Citation: Friesz, Melinda, Kira Muratov-Szabó, Andrea Prepuk, and Kata Váradi. 2021. Risk

Mutualization in Central Clearing: An Answer to the Cross-Guarantee Phenomenon from the Financial Stability Viewpoint. Risks 9: 148. https: / / doi.org/10.3390/risks9080148

Academic Editor: Mogens Steffensen

Received: 9 July 2021

Accepted: 12 August 2021

Published: 19 August 2021

Publisher's Note: MDPI stays neutral with regard to jurisdictional claims in published maps and institutional affiliations.

Copyright: (c) 2021 by the authors. Licensee MDPI, Basel, Switzerland. This article is an open access article distributed under the terms and conditions of the Creative Commons Attribution (CC BY) license (https:/ / creativecommons.org/licenses/by/ $4.0 /)$.

\begin{abstract}
Central counterparties' (CCPs) role is to take over the counterparty risk during trading. To fulfill its role, a CCP needs to operate a multi-level guarantee system that can absorb losses of clearing members' defaults. Our main question is how the size of the guarantee system changes and how the cross-guarantee undertaking changes between clearing members and markets if the CCP merges the guarantee systems of different markets. This question is essential from a financial stability perspective since the size and the structure of the guarantee system will affect the loss-absorbing capacity of a CCP. We used Monte Carlo simulation to simulate a 30 year time-series for three different products, which gave us the basis for the value-at-risk-based margin calculation and the stress-test-based default fund calculation. Results show that merging the guarantee systems will always decrease the total value of the guarantees because the margin will decrease, which cannot be offset by the increase in the default fund size. We conclude that it is not optimal from the financial stability perspective to merge the guarantee systems. However, if the CCP wants to provide cheaper services, or if the clearing members are willing to cross-guarantee each other, merging is more suitable.
\end{abstract}

Keywords: initial margin; default fund; central counterparty; stress test

\section{Introduction}

Over the last decade, the financial markets' regulatory changes have been aiming to increase the system's resilience and seeking to reduce systemic risk to increase financial stability. Financial stability means that the system is able to facilitate and enhance economic processes, can manage risk, and moreover, can absorb losses (Schinasi 2004). The structural modifications introduced require that over-the-counter (OTC) derivatives should be cleared through central counterparties (Platt et al. 2017). Authorities have also put great attention into strengthening the global safeguards for central clearing to prevent failures and massive distress by adopting the CPMI-IOSCO Principles for Financial Market Infrastructures in 2012, dedicated Financial Stability Board guidance, and the European Market Infrastructure Regulation (EMIR) in 2012.

The clearing activity of CCPs means that they take over counterparty risk during trading by becoming the buyer/seller of every sell/buy trade. According to this, if one of the trading partners defaults, the $\mathrm{CCP}$ will guarantee for the non-defaulting members that the trade will be fulfilled. To ensure financial resources that are enough to cover the losses caused by the default of one or more clearing members, a default waterfall system is operated. The three typical resources of the waterfall system are the initial margin (IM) requirements, the skin-in-the-game (SITG), and the default fund (DF) contributions. The default waterfall system, required to be operated by all CCPs, assures these market infrastructures' resilience and loss-absorbing ability to enhance financial stability in the 
economy. In Figure 1, the elements of this default waterfall system can be seen according to the requirements of Article 45 of the EMIR (2012) regulation, whose framework has been in force in the European Union since 2012. Our research is based on the EMIR, so we will not cover the requirements of other regulations related to CCPs' risk management, e.g., the Dodd-Frank Act (2010). Braithwaite and Murphy (2016) explains how the default waterfall system is built up and details its origin.

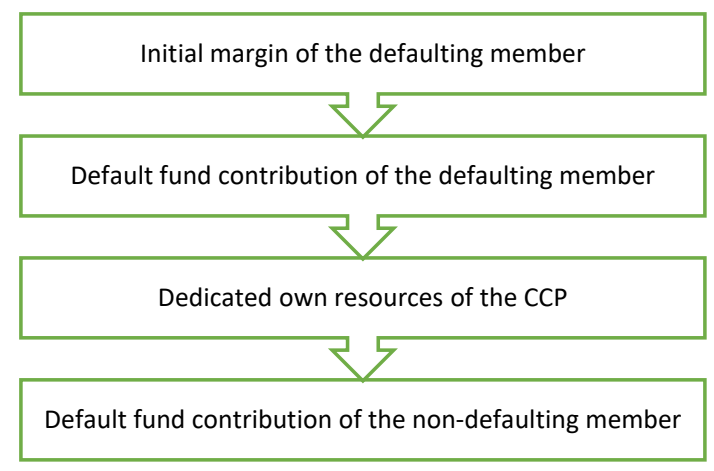

Figure 1. Default waterfall.

The exhaustion of the above-listed resources is far from random. EMIR requires using the available balances in a preordered sequence. The first resources to be exhausted are the initial margin requirements. According to Figure 1, a CCP at first can only use the margin to cover losses of the defaulting member but not the resources of the non-defaulting members. Based on EMIR Article 41 (EMIR 2012) and chapter VI of the regulatory technical standards (RTS 2013), the level of margin requirements should be set to cover potential market losses in the clearing members' positions in normal market conditions, based on the calculation of a statistical model. Procyclicality should also be taken into consideration (e.g., Glasserman and Wu 2017). The different procyclicality handling methods are being analyzed by Berlinger et al. (2018), while procyclicality was analyzed by King et al. (2020) from a liquidity point of view. The discrepancies related to margin calculation in the regulatory framework are interpreted by Murphy et al. (2014, 2016) and Szanyi et al. (2018).

Available margin resources are then followed by the default fund contribution sources based on Article 45 (EMIR 2012), which is the mutualized layer of resources provided by clearing members (Murphy 2017). This means that not only the defaulting member's contribution can be applied to cover losses by a CCP but the non-defaulting ones' as well. Nevertheless, in the second layer, only the defaulting members' default fund contribution can be used. Our paper defines the default fund on the $\max (1 ; 2+3)$ concept. This means that the default fund should, at least, enable the CCP to stand, under extreme but plausible market conditions based on Article 42 (EMIR 2012), for the clearing member's default with the greatest exposure or the sum of the second and third largest exposures of clearing members. Exposure means the losses that the value of the initial margin cannot cover. As a result, the smaller the initial margin is, the larger the default fund will be ceteris paribus (Murphy 2013; Nahai-Williamson et al. 2013; Cumming and Noss 2013). CCPs usually define the extreme but plausible market conditions in a stress test framework by creating historical and hypothetical stress scenarios. The scenarios should include the most volatile periods that the markets have experienced in the last thirty years for which the CCP provides its services (historical scenarios) and a range of potential future scenarios (hypothetical scenarios), taking into account the correlation between the different traded financial assets based on Article 30 (RTS 2013). The default fund contributions are proportional to the exposures of each clearing member (EMIR Article 42, RTS Chapter VII).

Risk management tasks do not stop here; the CCP itself also contributes some part of its own capital to the default waterfall system, which should be $25 \%$ of its minimum capital (RTS 2013, Article 35). This layer is called the skin-in-the-game. If all the defaulting members' resources are exhausted, the CCP's SITG will be consumed (McPartland and 
Lewis 2017). If this layer is not enough to cover the losses, the last layer will be applied, namely, the non-defaulting members' default fund contribution. This means that the cross-guarantee between clearing members appears in this layer. Baker (2021) and Huang and Takáts (2020) highlight the risks associated with the skin-in-the-game, including those that can shape incentives. Overall, CCPs and market participants should work together to ensure the most suitable practices are implied (Friesz 2020).

In practice, CCPs may decide to use an additional final layer, namely, a specific portion of the CCP's own capital, as a second skin-in-the-game, additional own resources (EACH 2021), but this layer is voluntary by the CCPs. If the default waterfall is still insufficient, recovery and resolution regimes are put into force (Cont 2015).

Principle 7 CPSS-IOSCO and the EMIR regulation introduce the Cover 2 concept as well, meaning that CCPs should have sufficient liquidity-should have enough guarantees within the whole default waterfall — to cover the simultaneous default of the two clearing members-and their affiliates-which would generate the most significant exposures against the CCP (Parkinson 2014). Murphy and Nahai-Williamson (2014) state that the Cover 2 standard is prudent, but in practice, it would be worth seeing the distribution of all of the losses to ensure that the guarantee system of the CCPs is robust enough in every case. Poce et al. (2018) support this and found that in the case of notable systemic events, the default fund is not adequate to cover losses in the Cover 2 concept, only in the case of very conservative CCPs. Capponi et al. $(2018,2020)$ have built up a method that could be used to define the optimal cover rule for defining the default fund. At the same time, Paddrik and Young (2017) show that two members' simultaneous failure could cause network contagion and lead to insufficient funds at the CCP. Campbell and Ivanov (2016) argue that the losses could be more substantial if large CCP members' exposures are positively correlated than if they are independent. Tywoniuk (2020) shows concern regarding potential contagion due to their high level of interconnectedness. Ghamami and Glasserman (2017) have found that lower default fund requirements reduce the cost of clearing but make CCPs less resilient. Barker et al. (2016) have analyzed the distribution of losses to default fund contributions and contingent liquidity requirements for each clearing member, identifying wrong-way risks among defaulting parties. Their main conclusion suggests that liquidity is the most important for members assessing the risks and costs.

Finally, Berndsen (2020) summarizes the most important research topics on CCPs, grouping them by the main fields they cover, namely, the clearing activity, the optimal number of CCPs, the default waterfall's size, the exhaustion of the default waterfall, and skin-in-the-game related researches. Also Menkveld and Vuillemey (2021) give a comprehensive summary of research on CCPs.

In our paper, we contribute to the existing literature as we analyze the effect of merging different market guarantee systems from the viewpoint of having a common default fund for different markets or having them separately for spot and derivative trades on the securities market. To our best knowledge, the literature lacks analysis on how merging different markets' default waterfall affects the structure and the size of the initial margin and default fund contributions of the clearing members. It is vital to notice that if the default funds are common in this paper, then the whole default waterfall will be handled as common. Our paper's primary focus will be to show how the margin and default fund size will change and how their value will change compared to each other. We analyze it on the whole guarantee system level and the individual clearing member level since we want to show the effect of risk mutualization. This means that we intend to analyze whether the risk-averse clearing members will take over risk from risk-seeking clearing members on the jointly cleared markets since the initial margin and default fund will increase for them ceteris paribus compared to the separated markets. We carried out our analysis on 30 year simulated data by applying a Monte Carlo simulation. In practice, it is common to have separated default funds (e.g., KELER CCP 2021) because separated default waterfalls do not mutualize risk. For example, it was seen in 2012 in the case of LCH.Clearnet, which split its default fund based on this reason (Jaidev 2012). 


\section{Related Literature of Stress Tests}

The size of the guarantees the clearing members have to pay is an essential question from their viewpoint not only on the individual clearing members' but also from the CCP's, since the lower the value of the margin and default fund, the lower the cost of trading, and liquidity risk can be decreased as well. In this paper, under liquidity risk, we mean the risk of not having enough resources by the clearing members to finance the margin and the default fund contribution requirements. From a CCP's point of view, the lower value of the guarantee system elements also means that it can have a competitive advantage in giving clearing services on the market. However, we should also keep in mind that the lower the guarantees' value, the higher risk is being run by the CCPs, since the guarantee system is not as vulnerable. From a systemic risk and a financial stability perspective, it is a crucial question since CCPs are systematically important financial institutions in the financial markets. So what may be optimal for the individual participants-whether they are the clearing members or the CCPs themselves-is not necessarily good from a financial stability perspective. Due to the interconnectedness of CCPs, many have criticized the risk CCPs carry as "being too big to fail" due to their continually growing importance (ChamorroCourtland 2011; Cont 2015; Duffie et al. 2015; Berlinger et al. 2018). Markose et al. (2012) mentions the concept of "too interconnected to fail", fearing the domino effect in case of distress. This systematic risk aspect has been analyzed by many from different viewpoints; for example, Biais et al. (2012) highlight moral hazard and risk monitoring (Biais et al. 2016) issues, while Lopez and Saeidinezhad (2017) analyze CCPs resilience, not in isolation, but potential spillovers on the rest of the financial system. They point out that regulators should implement further guidelines to assure financial stability. The supervisory stress tests, performed in 2019 in the EU and the United States, have started focusing more and more on the institutions' linkages (ESMA 2019; US CFTC 2016). McLaughlin and Berndsen (2021) recalled the main historical events of CCPs facing severe stress events. They conclude that legal discrepancies were acknowledged since the subprime crisis, and steps for improvements were taken. Faruqui et al. (2018) analyze the CCP-bank nexus, focusing on the two-way interactions between them. Along the balance sheet interlinkages and the structure of the CCP default waterfall, they show the nexus between them and highlight that the levels of stress change these interactions, and the endogenous build-up of risk connections can be harmful. King et al. (2020) analyze the events from September 2018 on the Swedish market, also discussing the benefits of CCPs.

We focused on the default funds' design, and we calculated the size of the default funds based on the stress test methodology, using a simulation of 30 years. According to EMIR (2012, Article 49), stress tests should be used to test and measure the risk management models of the CCPs in extreme but plausible market conditions. However, the regulatory framework may be vague in some aspects, so the methodologies and the most proper calibration of models gained immense attention. Novick et al. (2014) advise in their research that it would be necessary to mandate a standard stress test methodology for all CCPs. On the contrary, in practice, a wide variety of models have been developed to determine the adequate stress testing method. For example, the design of stress scenarios was analyzed by Canabarro (2013), while Poce et al. (2018) introduced a network-based stress test for CCPs. Bo et al. (2021) showed the premature failure of a CCP during a market shock if it loses its superiority to bilateral clearing. Paddrik and Young (2021) indicated that on CDS markets, conventional stress testing approaches may underestimate the potential threats of a CCP.

Stress tests aim to measure the resilience of an institution to ensure the availability of adequate resources. Furthermore, interconnectedness and systemic risks are also quantified. Therefore, the institutions themselves mark a set of parameters and shock the systems with independent events. The results define risk factor changes and then outline the extent of losses suffered in different scenarios. Madar (2010) defines stress tests as the techniques that measure the effects of rarely occurring events that are not measurable by the usual 
toolkit on financial institutions (Madar 2010). The exact course of preparing stress tests is described in detail by Hilbers and Jones (2004).

The types of stress tests may differ based on grouping principles. The BCBS (2009) groups test by the sensitivity analysis complexity or the built scenario applied. While Cihák (2007) argues the institution's scope versus the whole financial system, the Central Bank of Hungary (2019) advises bottom-up or top-down analysis. Hull (2015) defines the historical and hypothetical sources of scenarios, and Banai et al. (2013) run stress tests built upon the number of risks taken into consideration. The number of assets tested and the applied time horizon of the stress test may also be criteria.

In recent years, regulators set out a stress test methodology framework, called the "EU wide stress test", performed by the European Securities Market Authority (ESMA) at least annually. The latest stress tests were published in July 2020 (ESMA 2020). With local authorities, ESMA applies common methodologies for assessing the effect of different stress scenarios and has identified the shortcomings in the institutions' resilience. During the tests, credit, liquidity, concentration risk, and reverse credit stress are analyzed.

\section{Model}

Our main question is how the default waterfall's size and structure changes regarding the initial margin and default fund size if we clear two markets separately or jointly and how it affects risk mitigation. We chose two markets: the spot market for securities and the derivative market for these securities. It was important to select two markets that have a connection with each other because we wanted to show how the risk mitigation of the hedged positions between the spot and derivative assets changed the riskiness of the positions of the clearing members, and as a consequence, the guarantees the clearing members have to pay after their positions. We built a theoretical model using a Monte Carlo simulation (MCS). During our analysis, we did not simulate or include the value of the SITG. Our model had one CCP, four different clearing members, and three different financial assets: a stock, a bond, and a currency. The stock could be traded on the options, futures, and spot markets, while the bond could be traded only on the futures and spot markets, and the currency could be traded only on the options and futures markets. For the MCS, we had to have an assumption for the financial assets' price evolution since we needed a time-series for initial margin calculation and for estimating the default fund. We chose the arithmetic Brownian motion (ABM) to simulate the daily logreturns of the stock and the currency, while we chose the Vasicek model (Vasicek 1977) to simulate the instantaneous rate in the case of the bond. Based on this, Equation (1) shows the ABM we use for the stock and the currency:

$$
d Y=\alpha \cdot d t+\sigma \cdot \sqrt{d t} \cdot N(0,1)
$$

where " $d Y^{\prime}$ " is the change in the logreturn during " $d t$ " period, " $\alpha$ " is the expected value of the logreturn, " $\sigma$ " is the standard deviation for the logreturn, and " $N(0,1)$ " is a standard normal random variable. The price is determined by Equation (2), where " $t$ " stands for time, and " $S$ " stands for the asset's price:

$$
S_{t}=S_{0} \cdot e^{Y_{t}}
$$

In our simulation, the stress test had a central role. We simulated 30 years-since this is the look-back period for defining historical scenarios within the EMIR regulation-for both financial assets. To simulate the price of the stock and the currency, we set the value of the parameters needed to run the simulation. Moreover, to use "realistic" values in the simulation, which represent the European stock market and currency market, we estimated the expected value of the logreturn $(\alpha)$ and standard deviation $(\sigma)$-between 12 January 1991 and 11 January 2021 - of the DAX index, and - between 1 December 2003 and 11 January 2021—for the EUR/USD (Finance.yahoo.com 2021a, 2021b). Unfortunately, the time-series for the EUR/USD was not available for 30 years since the EUR has not existed 
for 30 years. The first day's price in the simulation was the price of DAX on 12 January 1991 and the price of EUR/USD on 1 December 2003. The applied parameters can be seen in Table 1.

Table 1. The parameters of the price simulation in the case of the stock and the currency.

\begin{tabular}{ccc}
\hline Parameter & Stock & Currency \\
\hline$\alpha$ & $7.71 \%$ & $0.09 \%$ \\
$\sigma$ & $22.37 \%$ & $11.85 \%$ \\
$S_{0}$ & 1345.26 & 1.1965 \\
$d t$ & 1 day & 1 day \\
\hline
\end{tabular}

In the case of the bond, we applied the Vasicek model (Vasicek 1977) determined in Equation (3):

$$
d y_{t}=a \cdot\left(b-y_{t}\right) d t+\sigma * \sqrt{d t} \cdot N(0,1)
$$

where " $d y$ " is the change in the instantaneous interest rate " $y$ "; " $a$ " is the speed of reversion to " $b$ ", which is the long term mean level; " $\sigma$ " is the instantaneous volatility of " $y$ ". Based on the model, the bond price (" $P$ ") is the following according to Equations (4)-(6), where " $T$ " is the maturity of the bond (Mamon 2004).

$$
\begin{gathered}
A(t, T)=\frac{1-e^{-a(T-t)}}{a} \\
D(t, T)=\left(b-\frac{\sigma^{2}}{2 a^{2}}\right)[A(t, T)-(T-t)]-\frac{\sigma^{2} A(t, T)^{2}}{4 a} \\
P\left(t, T, y_{t}\right)=\exp \left(-A(t, T) y_{t}+D(t, T)\right)
\end{gathered}
$$

The applied parameters for the bond price simulation can be seen in Table 2. The parameter estimation basis is the monthly time-series data of the term structure of interest rates on listed federal securities with a residual maturity of 0.5 years between the time period of January 1991 and December 2020, also for 30 years for the stock and the currency.

Table 2. The parameters of the price simulation in case of the bonds.

\begin{tabular}{cc}
\hline \multicolumn{1}{c}{ Parameters for the Price Simulation } \\
\hline Vasicek & Bond \\
$a$ & 5 \\
$\sigma$ & $2.49 \%$ \\
$b$ & $12.20 \%$ \\
$y_{0}$ & $2.69 \%$ \\
$T$ & 5 \\
$d t$ & 1 day \\
Face value & 100 \\
\hline
\end{tabular}

In addition to the price evolution for the financial assets, we also assumed a correlation between the three financial assets' returns. They did not evolve independently from each other. The correlation was taken into account through the $N(0,1)$ standard normally distributed random number in all three processes. We applied the Cholesky decomposition, which means that the relation between the random variables is the following, based on Equations (7)-(9) (Medvegyev and Száz 2010), where " $\epsilon$ " will be a random number used in case of the three assets, and " $\rho$ " is the correlation coefficient.

$$
\begin{gathered}
\epsilon_{\text {stock }}=N(0,1)_{\text {Stock }} \\
\epsilon_{\text {currency }}=\rho \cdot N(0,1)_{\text {Stock }}+\sqrt{1-\rho^{2}} \cdot N(0,1)_{\text {Currency }}
\end{gathered}
$$




$$
\epsilon_{\text {bond }}=\rho \cdot N(0,1)_{\text {Stock }}+\frac{\rho-\rho^{2}}{\sqrt{1+\rho^{2}}} \cdot N(0,1)_{\text {Currency }}+\sqrt{1-\rho^{2}-\frac{\left(\rho-\rho^{2}\right)^{2}}{1-\rho^{2}}} \cdot N(0,1)_{\text {bond }}
$$

The correlation between the assets is 0.2 in normal market conditions. However, in our price simulation, it was not enough to capture the normal market conditions since we needed stress/shocks in the simulated time-series as well. As we stated before, the initial margin stands for covering possible losses in normal market conditions, while the default fund should cover the losses in extreme but plausible market conditions, which we estimate with stressed market events. As a result, we modified the simulation of the logreturns of the three assets by simulating stresses in the time-series of assets' returns as well, so the ABM and Vasicek were not enough for us as we presented before. The stress/shock occurrence was modeled with a Poisson process, while the extent of the shock was modeled with a lognormal distribution. The correlation at the time of the shock-in the case of any of the assets-was increased to 0.95 , and it decreased by 0.95 every day. The applied parameters for the model are the following according to Table 3 , while a realization of the stock price and one realization of the shock can be seen in Figure 2.

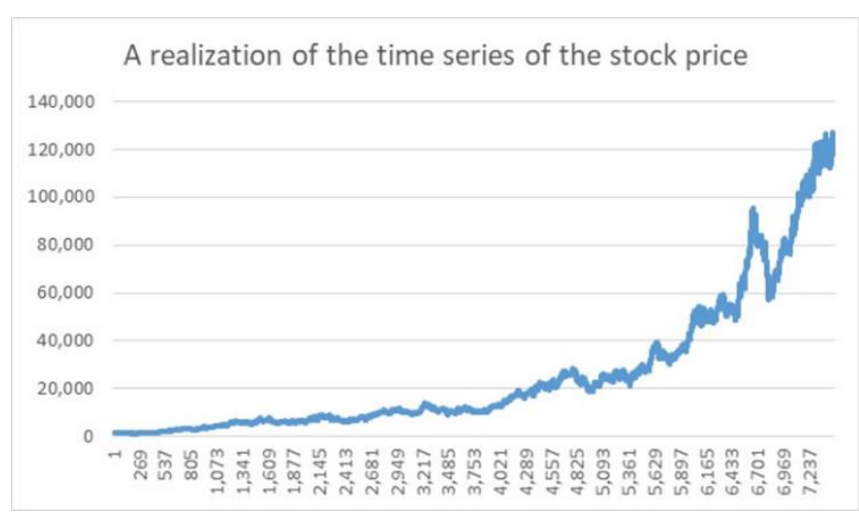

(a)

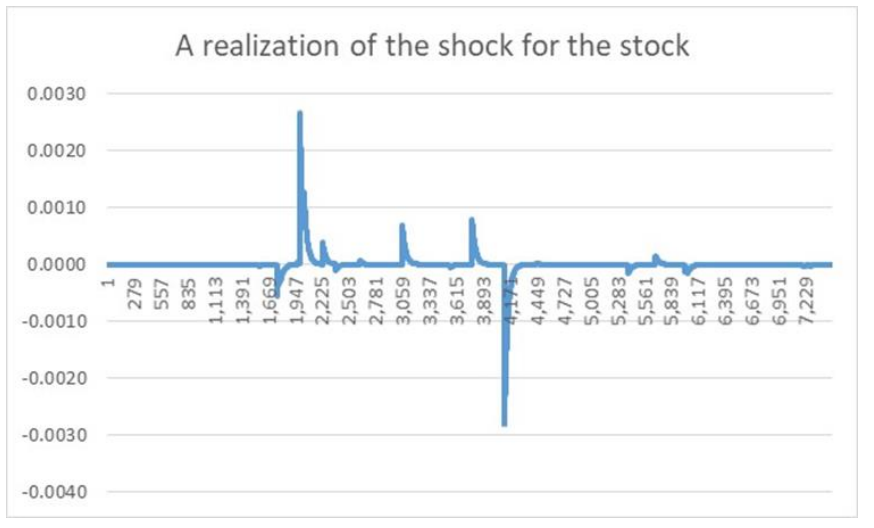

(b)

Figure 2. (a) Realization of the stock price; (b) Realization of the shocks.

Table 3. The parameters of the shock simulation.

\begin{tabular}{|c|c|c|c|}
\hline \multicolumn{4}{|c|}{ Shock Parameter Affecting the Value of the Shock } \\
\hline & Stock & Currency & Bond \\
\hline$\mu$ & -10.00 & -10.00 & -10.00 \\
\hline$\sigma$ & 2.25 & 2.25 & 2.25 \\
\hline decrease of shock & 0.97 & 0.97 & 0.97 \\
\hline \multicolumn{4}{|c|}{ Shock Parameters Affecting the Date of the Shock } \\
\hline$\lambda$ & 0.005 & 0.0045 & 0.004 \\
\hline
\end{tabular}

Four clearing members $(\mathrm{CM})$ were present on the market, with different positions according to Table 4 . The positions of the clearing members were built in order to be able to analyze how the merged and separated default funds affected the margin and default fund contributions of the markets. CM4 had positions only on the spot market, while the other clearing members had risky positions, such as short straddles, and also positions that handled risk, such as protective put or covered call positions. This is important because if the markets are cleared separately, this risk hedging cannot be used by the clearing members regarding initial margin and default fund payment, while on the merged market, they can hedge the risk. CM3 takes the riskiest position since it has large unhedged short futures positions and also unhedged short straddles as well. 
Table 4. Number of positions of clearing members.

\begin{tabular}{|c|c|c|c|c|c|c|c|c|c|c|c|c|}
\hline \multirow{2}{*}{$\begin{array}{c}\text { Position of } \\
\text { Clearing } \\
\text { Members }\end{array}$} & \multicolumn{3}{|c|}{ Clearing Member 1} & \multicolumn{3}{|c|}{ Clearing Member 2} & \multicolumn{3}{|c|}{ Clearing Member 3} & \multicolumn{3}{|c|}{ Clearing Member 4} \\
\hline & Stock & Bond & Currency & Stock & Bond & Currency & Stock & Bond & Currency & Stock & Bond & Currency \\
\hline Long Put & 3 & & 5 & 2 & & & & & & & & \\
\hline Short Put & & & & & & & 5 & & 5 & & & \\
\hline Long Call & 3 & & 5 & & & & & & & & & \\
\hline Short Call & & & & & & & 3 & & 5 & & & \\
\hline Long Futures & & 5 & & & 5 & 5 & & & & & & \\
\hline Short Futures & & & 5 & & & & & 10 & & & & \\
\hline $\begin{array}{c}\text { Long } \\
\text { Underlying }\end{array}$ & & & & 2 & & & 3 & & & 6 & 5 & \\
\hline $\begin{array}{c}\text { Short } \\
\text { Underlying }\end{array}$ & 8 & & & & 5 & & & & & 3 & & \\
\hline $\begin{array}{l}\text { Name of } \\
\text { position }\end{array}$ & $\begin{array}{l}\text { Long } \\
\text { straddle } \\
+ \text { spot }\end{array}$ & Futures & $\begin{array}{c}\text { Long } \\
\text { straddle } \\
+ \text { futures }\end{array}$ & $\begin{array}{l}\text { Protective } \\
\text { put }\end{array}$ & $\begin{array}{c}\text { Futures } \\
+ \text { spot }\end{array}$ & Futures & $\begin{array}{c}\text { Covered } \\
\text { call + } \\
\text { short } \\
\text { straddle } \\
+ \text { spot }\end{array}$ & Futures & $\begin{array}{l}\text { Short } \\
\text { straddle }\end{array}$ & Spot & Spot & - \\
\hline
\end{tabular}

In the following, we show how we estimate the initial margin and the default funds from the simulated times series data and the clearing members' positions. The margin of the underlying assets (stock, bond, currency) is calculated by Béli and Váradi's (2016) method. This model is based on the delta-normal value-at-risk (VaR) calculation (Jorion 2007) using different standard deviations to quantify the VaR value. Namely, we calculated the equally weighted standard deviation $\left(\sigma^{\text {equal }}\right)$ and the exponentially weighted moving average (EWMA) standard deviation ( $\sigma^{E W M A}$ ) of the time-series of the simulated logreturns (from Equation (1)) in the case of the stock and the currency, while in the case of the bond, the standard deviations should be calculated for the change of the simulated returns from the Vasicek model. Always that type of standard deviation is applied, which has a lower value, according to Equations (10) and (11),

$$
\begin{gathered}
\operatorname{VaR} R_{t}^{y}=\min \left(\sigma^{\text {equal }} \cdot N^{-1}(99 \%) ; \sigma^{E W M A} \cdot N^{-1}(99 \%)\right) \\
\operatorname{VaR} R_{t, \text { bond }}^{y}=D^{*} \cdot \min \left(\sigma^{\text {equal }}\left(\Delta y_{t}\right) \cdot N^{-1}(99 \%) ; \sigma^{E W M A}\left(\Delta y_{t}\right) \cdot N^{-1}(99 \%)\right)
\end{gathered}
$$

where $N^{-1}(99 \%)$ is the inverse of the normal distribution's cumulative distribution function at the $99 \%$ probability, $D^{*}$ is the modified duration of the bond, $V a R_{t}^{y}$ is the value-at-risk at day $t$ for the logreturn $(y)$ in case of the stock and the currency, while $V a R_{t, b o n d}^{y}$ is the value-at-risk for the bond's logreturn. The value-at-risk expressed for the price instead of the logreturn is based on Equations (12) and (13), where $S$ is coming from the ABM (Equations (1) and (2)), while $P$ is coming from the Vasicek model (Equations (3)-(6)), and $T$ is the liquidaton period, which is set to 2 days, based on the regulation (EMIR 2012; RTS 2013),

$$
\begin{aligned}
& V a R_{t}^{\text {price }}=-S_{t}+S_{t} \cdot e^{\sqrt{T} \cdot V a R_{t}^{\text {yield }}} \\
& \operatorname{VaR}_{t, \text { bond }}^{\text {price }}=a b s\left(P_{t} \cdot V a R_{t, \text { bond }}^{y}\right)
\end{aligned}
$$

Additionally, a $25 \%$ procyclicality buffer was used. It was exhausted and built back based on the two standard deviations, and it worked the same way for all of the three products, so we will not highlight the bond separately as in the case of Equations (10)-(13). If the EWMA standard deviation is greater, then the buffer is exhausted gradually. If the equally weighted standard deviation is greater, it is gradually built back, according to Equations (14)-(16), where $\pi$ stands for the procyclicality buffer

$$
\text { PROmargin }_{t}=\text { VaR }_{t}^{\text {price }} \cdot(1+\pi)
$$




$$
\begin{gathered}
\operatorname{margin}_{t}^{\pi \text { exhaustion }}=\max \left(\text { margin }_{t-1} ; \text { VaR }_{t}^{\text {price }}\right) \\
\text { margin }_{t}^{\pi \text { built back }}=\min \left(\operatorname{margin}_{t}^{\pi \text { exhaustion }} ; \text { PROmargin }_{t}\right)
\end{gathered}
$$

Finally, the margin at time $t$ is defined by Equations (17)-(21) for all three products by calculating a so-called margin band with a minimum and maximum margin value in Equations (17) and (18).

$$
\begin{gathered}
\text { MINmargin } \\
=\text { if }\left(\sigma^{E W M A} \cdot \max \left(\frac{\text { margin }_{t-1}}{\operatorname{VaR}_{t}^{\text {price }}} ; 1\right)>\sigma^{\text {equal }}\right) \\
\operatorname{margin}_{t}^{\pi \text { built back }} ; \text { PROmargin }_{t} \\
\text { MAXmargin }_{t}=\text { MINmargin } \cdot(1+\text { band })
\end{gathered}
$$

If the calculated margin in Equations (10)-(16) does not reach this minimum or maximum value, the margin requirement will not change, according to Equations (19)-(21). The main goal of this calculation is to stabilize the value of the margin, not to have to change it on a daily basis, which is essential in practice from the clearing members' liquidity management point of view.

$$
\begin{aligned}
& \operatorname{margin}_{t}=i f\left(\operatorname{margin}_{t-1}>M A X \operatorname{margin}_{t} ; M A X \operatorname{margin}_{t}\right) \\
& \operatorname{margin}_{t}=i f\left(\operatorname{margin}_{t-1}<\operatorname{MINmargin}{ }_{t} ; \operatorname{MINmargin}\right)_{t}
\end{aligned}
$$

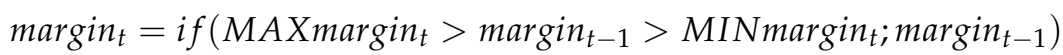

After defining the margin on the individual asset level, we quantified the portfolio level margin. We carried it out by using the SPAN (standard portfolio analysis of risk) method by applying some simplification. The SPAN is a complex method, according to Figure 3 (CME Group 2019).

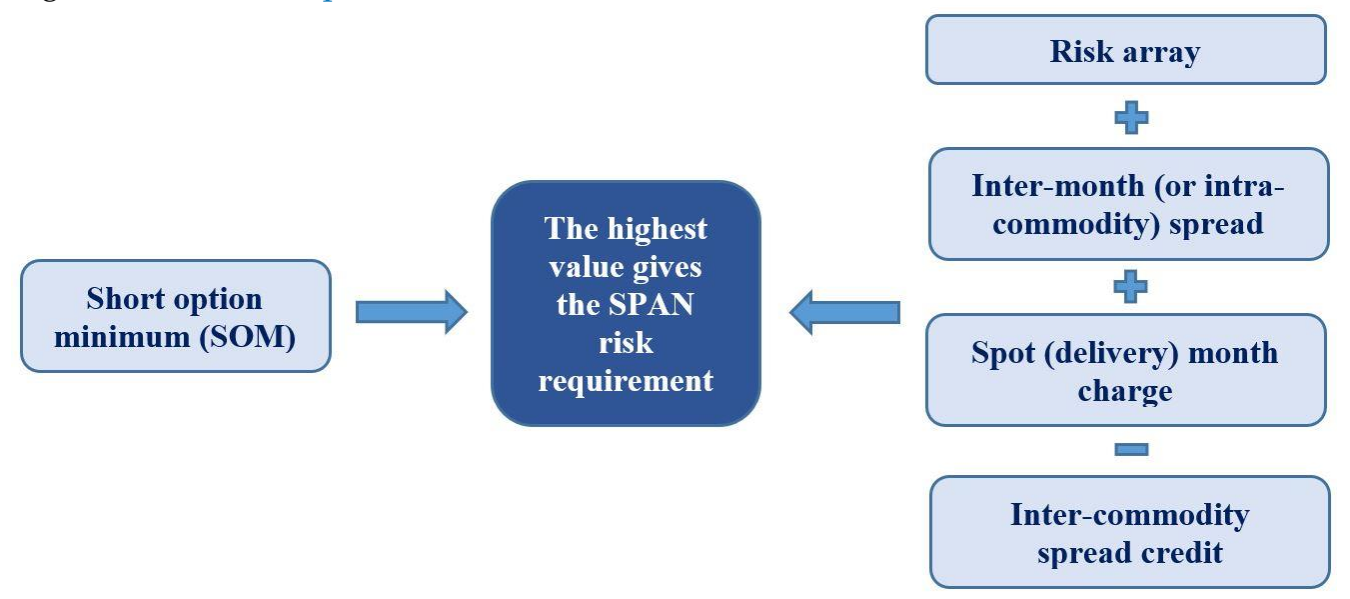

Figure 3. SPAN methodology.

For simplicity, we assumed that there was only a risk array and short option minimum (SOM), which would be $10 \%$ of the underlying asset's margin, except in the case of the bond; since there are no options, SOM is not needed either. The risk array contains scenarios for the portfolio, according to Table 5. This means that the positions are revalued with the new underlying asset prices and new standard deviations. The scenario that gives the most significant loss is considered the margin (the Margin ${ }_{\mathrm{CMt}}$ in Equation (22)) of a particular $\mathrm{CM}$ portfolio. One unit of change in the spot price is the value of the asset's actual margin calculated in Equations (10)-(21), while one unit of change in the standard deviation is $90 \%$ of the actual daily standard deviation. 
Table 5. SPAN scenario parameters.

\begin{tabular}{ccc}
\hline Scenario & $\begin{array}{c}\text { The Change in Spot Price Will } \\
\text { Be Multiplied by This Amount }\end{array}$ & $\begin{array}{c}\text { The Change in Standard Deviation } \\
\text { Will Be Multiplied by This Amount }\end{array}$ \\
\hline 1 & 0.00 & 1 \\
2 & 0.00 & -1 \\
3 & 0.33 & 1 \\
4 & 0.33 & -1 \\
5 & -0.33 & 1 \\
6 & -0.33 & -1 \\
7 & 0.67 & 1 \\
8 & 0.67 & -1 \\
9 & -0.67 & 1 \\
10 & -0.67 & -1 \\
11 & 1.00 & 1 \\
12 & 1.00 & -1 \\
13 & -1.00 & 1 \\
14 & -1.00 & -1 \\
15 & 2.00 & 0 \\
16 & -2.00 & 0 \\
\hline
\end{tabular}

During portfolio-based margining, we determined the price of the options with the Black-Sholes model (Black and Scholes 1973). We assumed the following: the options are ATM options, with a maturity of one year; the standard deviation is the actual daily standard deviation that is used in the margin model; the one-year risk-free return is calculated with the Vasicek model; in the case of the currency option, the counter currency's risk-free return is $0 \%$. The futures positions have the same parameters as the options.

We simulated the margins on a portfolio level in two different ways, once when the margin and default fund were calculated for the spot and derivative markets as merged markets and once when they were separated. This is important because during the portfolio margining with the SPAN method in the merged case, the spot position could be hedged with the derivative position, hence, the risk is lower; therefore, the margin should be lower for the portfolio, while in the separated case, one portfolio is for the spot positions, and another portfolio is for the derivative positions, hence, the risk should be higher, and the margin should be higher as well. In our analysis, we aim to show this phenomenon, and also we want to show how it affects the value of the default fund, and as a final effect, how the size of the guarantees will change.

To calculate the default fund, we needed to run the stress test based on the EMIR (2012) regulation and Hull (2015). We estimated historical and hypothetical scenarios as well. Altogether, we had eight stress scenarios: six historical and two hypothetical in our stress test. In every scenario, we had a stress parameter for all three financial assets, one for the stock, one for the currency, and one for the bond. We used the same stress scenarios on the spot and derivative markets. The focus of our stress test was to see if we stress the current market price-which is the last simulated price in our price simulation with ABM and Vasicek, so the 7500th day-with every stress scenarios' stress parameters, would the margin be enough to cover the potential losses in case the CM defaulted. According to EMIR, the value of the default fund is the scenario that has the highest loss of the max $(1 ; 2+3)$ exposures. We appled the following rule to define the historical scenarios: we took the simulated 30 year time-series and searched for the day where the stock had the lowest return. On this same day, we took the return of the bond and the currency as well. This was one scenario, and we named this "min stock." The other five historical scenarios were based on the same method; summarized in the following, the six historical scenarios can be seen:

- Historical 1-Min stock: lowest stock return during the 7500 days and taking the currency returns and the bond yield change on the same day. 
- Historical 2-Max stock: highest stock return during the 7500 days and taking the currency returns and the bond yield change on the same day.

- Historical 3-Min bond: lowest yield change during the 7500 days and taking the stock and currency returns the same day.

- Historical 4-Max bond: highest yield change during the 7500 days and taking the stock and currency returns the same day.

- Historical 5-Min currency: lowest currency return during the 7500 days and taking the stock returns and bond yield change the same day.

- Historical 6-Max currency: highest currency return during the 7500 days and taking the stock returns and bond yield change the same day.

In hypothetical scenarios, we must consider the correlation between the different risk factors and risk parameters. To fulfill the regulator's requirements, we chose the stress parameters the European Systemic Risk Board (ESRB) put together during the EU-wide stress test for the central counterparties in 2019. The test's time horizon was five days, but we ran our test only on a daily time horizon, so we converted the given parameters to daily ones. For the DAX index, $-14 \%$ was given by the ESRB, so on a daily basis, it became $-2.80 \%$; the shortest government bond stress parameter belonged to the 1-year maturity bond, which was -36 basis points, so we applied -7.2 basis points. For the EUR/USD, the USD/EUR parameter was set at $-5.8 \%$, which means that the EUR/USD parameter was $6.16 \%$, and on a daily basis it was $1.23 \%$ (ESRB 2019). We had two hypothetical scenarios, one with the parameters explained and another with the opposite of these numbers. An example of the eight stress scenarios based on our price simulation can be seen in Table 6 .

Table 6. An example of the stress scenarios.

\begin{tabular}{ccccccccc}
\hline & \multicolumn{3}{c}{ Historical Scenarios } & & \multicolumn{2}{c}{ Hypothetical Scenarios } \\
\hline Parameters & $\begin{array}{c}\text { Min } \\
\text { Stock }\end{array}$ & $\begin{array}{c}\text { Max } \\
\text { Stock }\end{array}$ & $\begin{array}{c}\text { Min } \\
\text { Currency }\end{array}$ & $\begin{array}{c}\text { Max } \\
\text { Currency }\end{array}$ & $\begin{array}{c}\text { Min } \\
\text { Bond }\end{array}$ & $\begin{array}{c}\text { Max } \\
\text { Bond }\end{array}$ & First & Second \\
\hline Stock & $-5.28 \%$ & $4.71 \%$ & $-0.48 \%$ & $-1.59 \%$ & $-1.59 \%$ & $0.08 \%$ & $-2.80 \%$ & $2.80 \%$ \\
Bond & $0.00 \%$ & $0.00 \%$ & $0.00 \%$ & $0.00 \%$ & $0.03 \%$ & $-0.02 \%$ & $-0.07 \%$ & $0.07 \%$ \\
Currency & $-1.26 \%$ & $0.13 \%$ & $-2.69 \%$ & $2.90 \%$ & $0.92 \%$ & $-0.29 \%$ & $1.23 \%$ & $-1.23 \%$ \\
$\begin{array}{c}\text { Number day in the } \\
\text { simulation }\end{array}$ & 6839 & 179 & 3380 & 915 & 5897 & 5576 & \\
\hline
\end{tabular}

Overall, we define the largest and the sum of the second and third largest exposure (loss not covered by the initial margin) in every historical and hypothetical scenario. That scenario will "win" that has the largest exposure, so the one that had the largest max $(1 ; 2+3)$ value. Moreover, this value will be the value of the default fund (DF).

As a final step, this default fund (DF) is split up between the clearing members according to their ratio of margin payment within the total margin value on the market, according to Equation (22),

$$
\mathrm{DF}_{\mathrm{CM} 1}=\frac{\operatorname{Margin}_{\mathrm{CM} 1}}{\sum_{t=1}^{4} \operatorname{Margin}_{\mathrm{CMt}}}
$$

\section{Results}

We ran the simulation 1000 times within the model we introduced in the previous chapter. Figure 4 shows the default funds' values in the cases of merged and separated markets for 1000 realizations. In the separated DF-s, the value shown in Figure 4 is the sum of the DF of the spot and the derivative market. We cleaned our database of eight outlier values in order to represent the results since, in these outlier cases, the size of the default fund was so high that one graph could not contain all of them at once; the outliers can be seen in the right upper corner of Figure 4. 


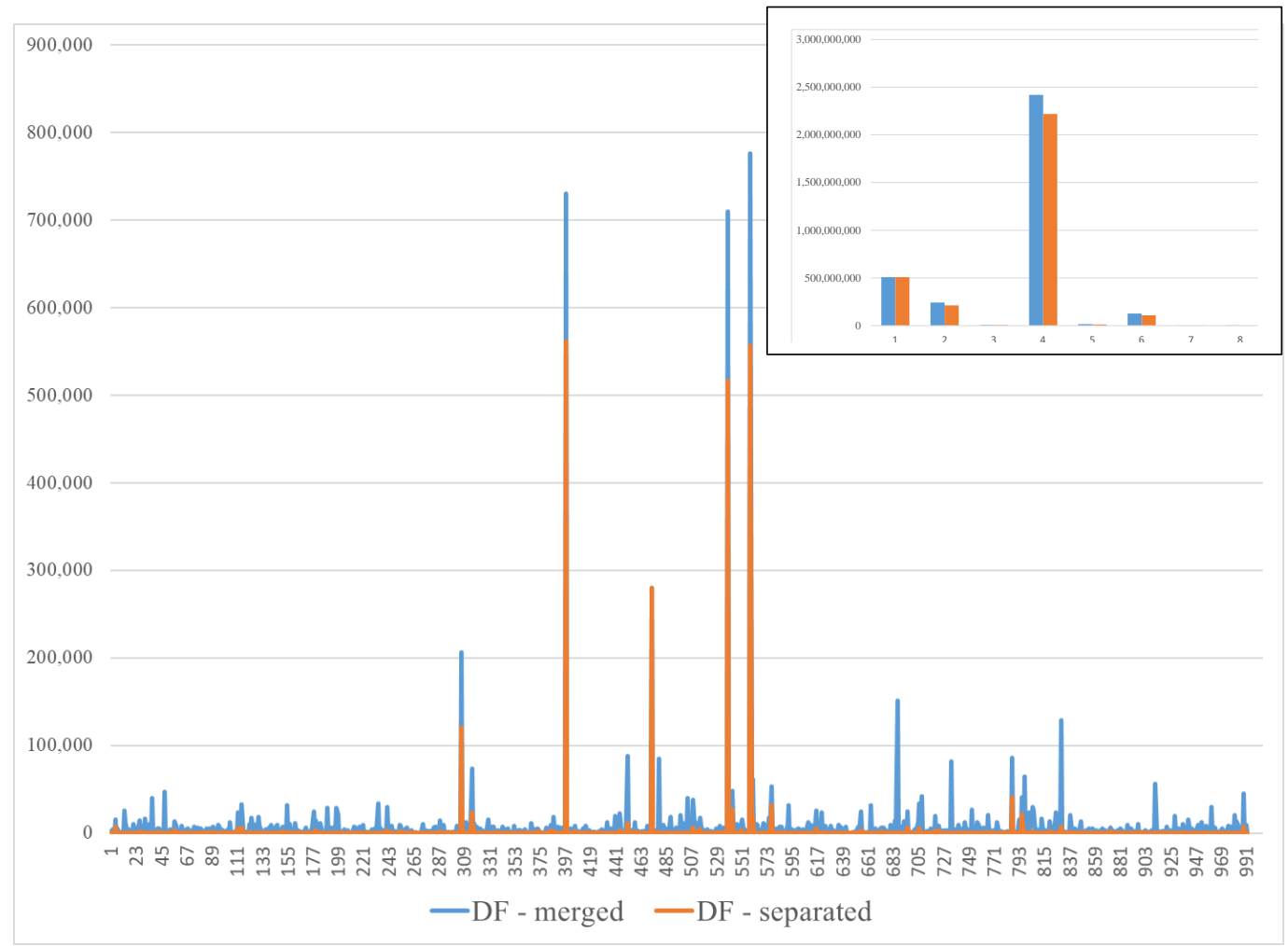

Figure 4. Size of the default funds in the two different cases.

A striking difference can be seen between the markets regarding the value of the default fund (DF), namely, that the DF's value was always higher in the merged market, which means that in the merged case, the cross-guarantee taken between the CMs became larger. Moreover, in the separated market, the DF value was 0 in 649 cases, while in the merged case, only one out of 1000. This is a vast difference, which is essential from a loss absorption point of view since zero DF value means that the value of the initial margin is enough to cover the losses both on the derivative and on the spot market as well in the separated structure, while in the case of the merged market, this could nearly never happen.

In the cleared dataset, the minimum DF value was zero in both market structures. While the separated DF had its maximum at 561,914, the merged DF was much higher: 776,197 . The difference between the average DF value was more significant since the merged DF values' average was more than three times as large, 7618 , while in the separated, it was only 2419.

One of our goals was to examine how the contribution to the default fund changed per each clearing member in the two different structures, since we wanted to analyze how risk mutualization changes. To show this, we looked at how the default fund contribution-not in absolute terms, but the percentage of the total value of the DF-changed for each clearing member in the two cases. The result can be seen in Figure 5 for those cases when the DF was not 0 in the separated case. Figure 5 shows the difference between each CMs' DF contribution within the merged and separated market. If the value is positive, the CM has a larger share in the DF in the merged case than in the separated, while if it is negative, the CM's share was smaller. 


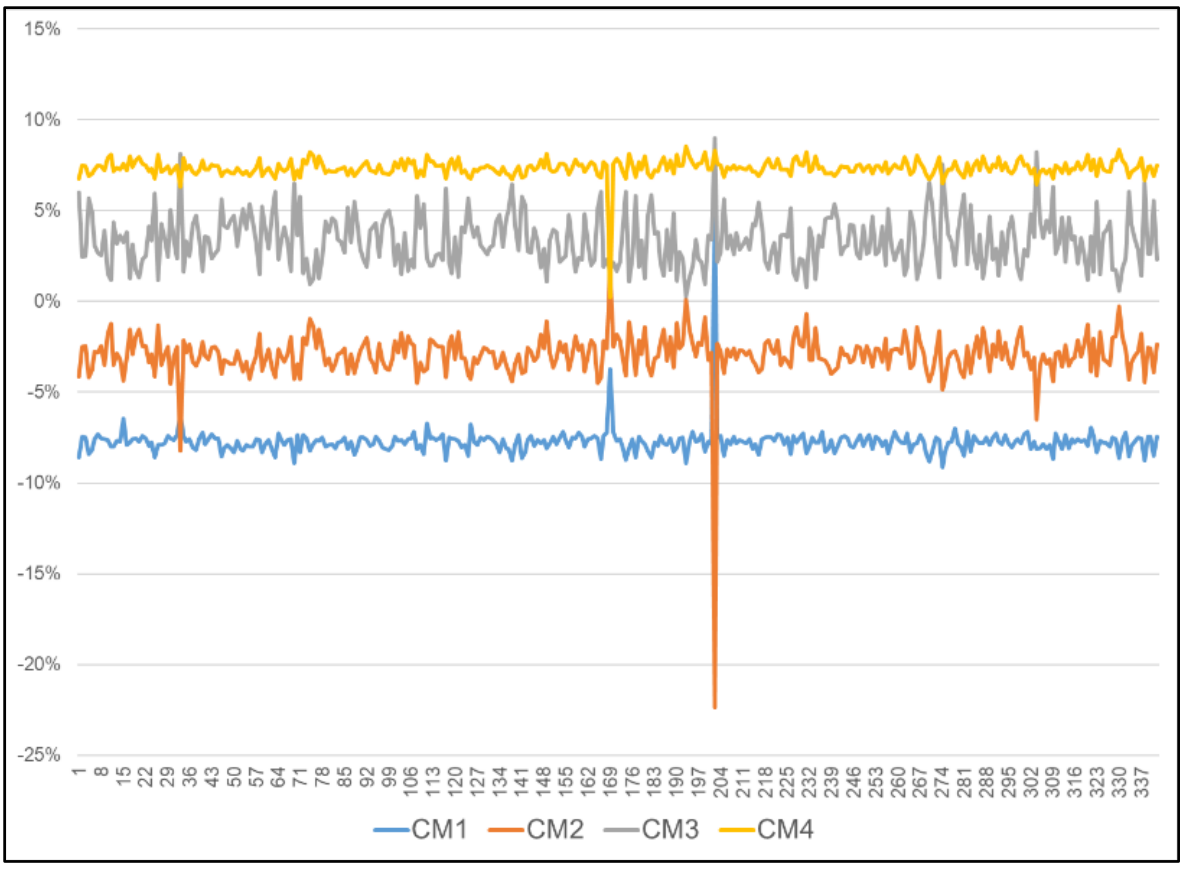

Figure 5. Difference between the DF contributions of each CMs.

The results show the DF contribution for $\mathrm{CM} 3$ and $\mathrm{CM} 4$ has always increased, while CM1 and CM2 consistently decreased, except one occasion out of the 1000 for CM1. CM3 only has net long positions in the stock and the bond, so it did not have any derivative positions. Merging the markets increases its share in the mutualized risk, so it has to face larger cross-guarantee commitments because of the high risk those traders take, who also trade on the derivative markets. However, on the other hand, CM4, which had taken the most considerable risk since it has several unhedged short options and huge unhedged short futures positions, also has to increase its share in the default fund. So its positions risk is mutualized, but at the same time, its guarantee payments had to be increased as well in relative terms compared to the other CMs. Interestingly, those two CMs-CM1 and CM2 - who have several hedged positions and could use the derivative products' risk hedging effect could decrease their DF payment contribution share.

The DF structure is impressive, as well as the whole guarantee system, namely, how the initial margin payment has changed and how the total value of the guarantees (IM + DF) changed. By analyzing the whole guarantee system, we can conclude that the total amount of guarantees is always higher in the separated markets, according to Figure 6. Figure 7 shows the difference between the two guarantee systems, which also shows that the guarantees' total value always decreases in the merged case. 


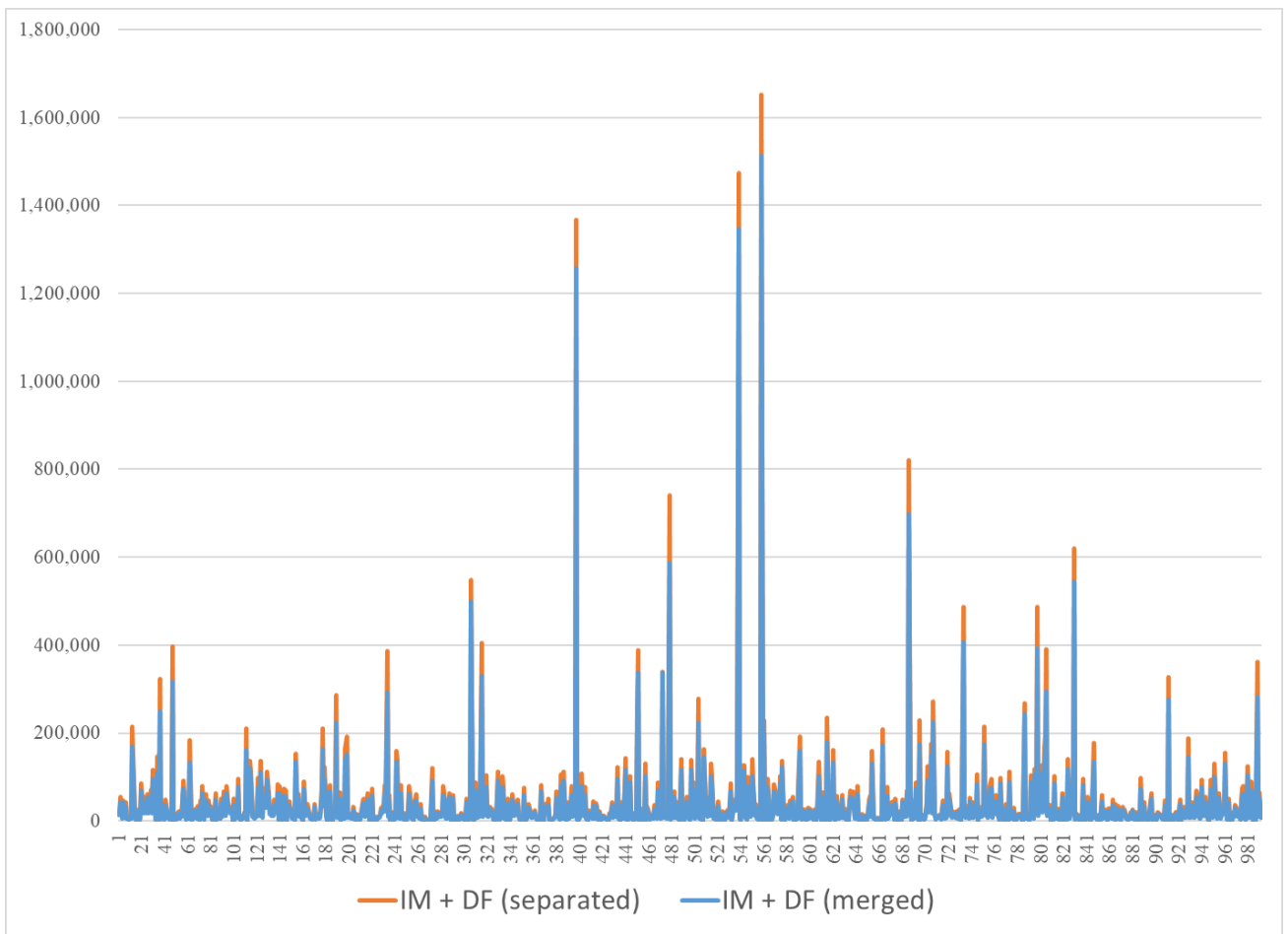

Figure 6. Total value of the guarantees in the merged and the separated case.

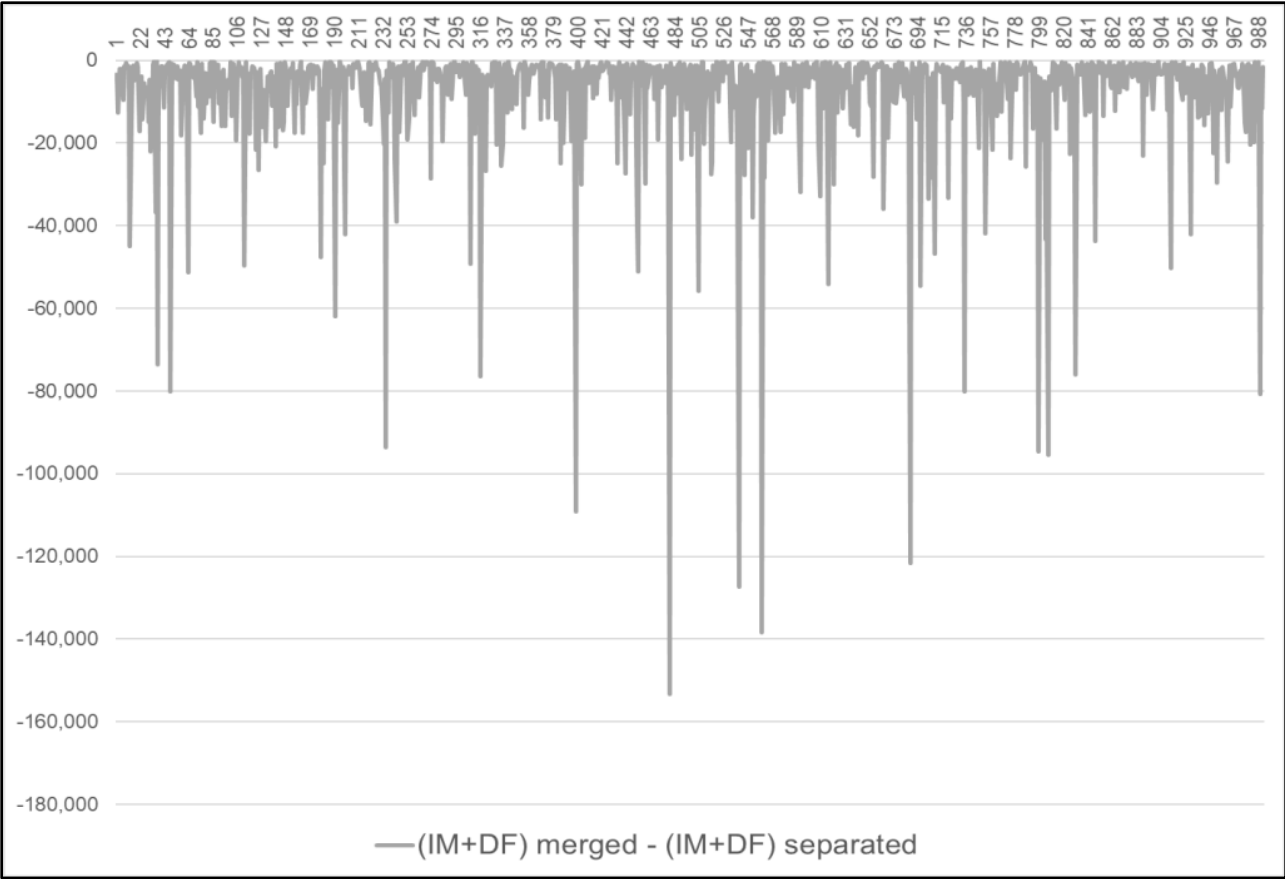

Figure 7. Difference between the guarantee values of the separated and merged markets.

This difference can be the consequence of the portfolio margining on the merged markets since the risk of the spot and derivative markets' positions cancel out, reflected in the margin values. In every case, the margin is higher on the separated markets than on the merged ones. The difference is presented in Figure 8. 


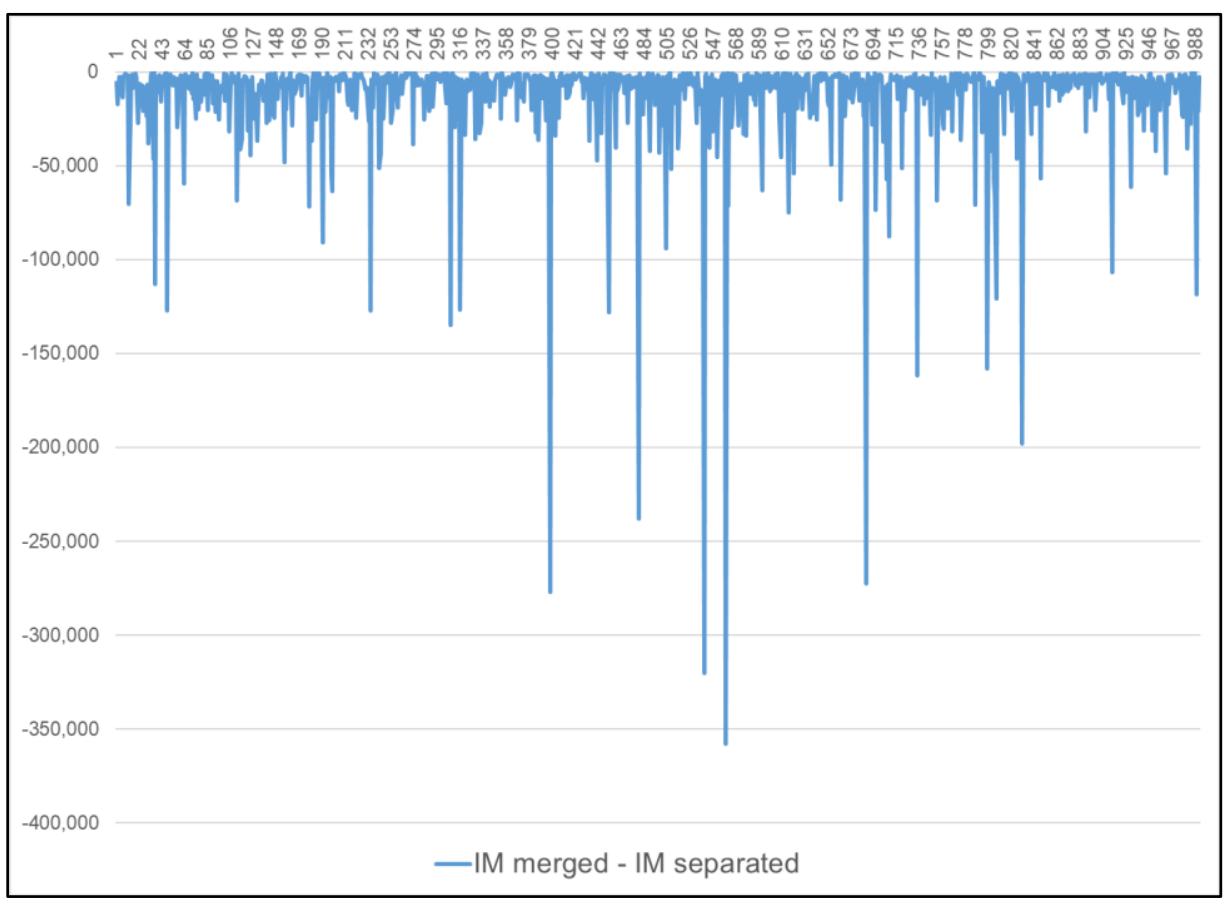

Figure 8. Difference between the margin values of the separated and the merged markets.

As a robustness check, we ran 1000 simulation a few times more, and the results always had the same patterns as the simulation we have shown.

\section{Discussion}

Our paper has set up a hypothetical market with one central counterparty, four clearing members, three underlying assets that can be traded on the spot market, and the derivative market as options or futures contracts. We have simulated a 30 year timeseries-7500 trading days-for all three assets in order to be able to calculate on the 7500th day the margin requirements and the default fund contributions the clearing members have to pay to the CCP after their open positions. The open positions were built up to show how the cross-guarantee undertaking changes if the CCP merges or separates the guarantee system - the default waterfall-for the spot and derivative markets. One of the members had mainly open short derivative positions, so this clearing member's portfolio represented a very risky portfolio. Another one had only positions on the spot market; with this, we represented how the cross-guarantee changes between markets. The remaining two had hedged open spot positions with derivative products, so they were active on both of the markets; therefore, we could show how the hedged positions' advantage from a risk reduction point of view is reflected in the amount of guarantees the clearing members have to pay. We also showed in our paper how the total size and the structure of the guarantee system changes.

The margin requirement and default fund calculation methodology were built on the EMIR regulation, which is the European regulation in force regarding central counterparties. It was important to comply with the EMIR regulation since we wanted to show in our paper whether the merged or the separated default fund structure was more prudent and, consequently, better from a financial stability point of view. The ultimate goal of CCPs is to be shock-resistant by protecting the financial system from one or more default events, preventing a domino effect from emerging, protecting the non-faulty market participant. This assures the smooth day-to-day operation of the system.

Our paper has pointed out why it is essential to carefully build a guarantee system and apply it jointly or separately for different markets. In addition to complying with the regulatory background, it is also crucial to carefully set up the risk management framework for a CCP. The amount of the margin can affect the amount of the default fund, which has 
different effects on the CCP and the CMs as well, not necessarily positively for both at the same time. Our model is a simplified reality, but the results show how much impact the merged and separated market has regarding cross-guarantee. Our primary goal was to examine how the contribution to the default fund and initial margin changed per each clearing member if we calculated on separated or merged markets and show how the total size of the guarantee system changed. The DF was higher on the merged market in all of the simulated cases. However, analyzing the whole guarantee system, we can conclude precisely the opposite, namely, the total amounts of guarantees are higher in the case of the separated markets. The difference can result from the portfolio margining on the merged markets since the risk of the spot and derivative markets' positions cancel out, as reflected in the margin values. We also found that the default fund contributions have increased on merged markets-compared to the separated markets-for the clearing members who traded only on the spot markets, so they have to take over some of the other clearing members' risks. Finally, from a financial stability viewpoint, we would recommend clearing the markets separately since the total value of the guarantees are larger in this case, so the loss-absorbing capacity of the CCP is larger.

\section{Conclusions}

In this paper, we analyzed how the size and the structure of the guarantee system changes if a central counterparty applied it for merged or separate markets. As a general conclusion, it can be stated that in the separated case, the overall guarantees that are available in the guarantee system are higher; however, the value of the default fund is always larger in the merged case, so the cross-guarantee between the clearing members and markets are more notable. From the clearing members' perspective, this result makes the merged markets more favorable, since in this case, the trading is cheaper for them, because less collateral is required to be posted. However, because the ratio of the cross-guarantee commitments changes, it is questionable if it is better from a risk-taking point of view for all of the clearing members or not. From the CCPs point of view, if it wants to increase its competitiveness by lowering the guarantees' value, the merged version should be chosen, but if it wants to have a more prudent guarantee system, the markets should be separated. Finally, from a financial stability point of view, since in the separated case, in more than $60 \%$ of the cases, the initial margin was enough to cover potential future losses, the default fund value was 0 , it can be stated that the separated markets are more stable andmore stress-resistant, so it should be chosen if the financial stability of the CCP is in focus.

From a regulatory perspective, our recommendation to policymakers, on the one hand, is to follow the more prudent path and specify the operation of the default funds to be handled separately. On the other hand, if the regulator's most important goal is to handle systemic risk, it must keep a balance between increasing the size of the initial margin and default fund and the liquidity risk it causes for the clearing members. Therefore, it is not evident that the higher initial margin and default fund value is adequate from a systemic risk point of view. This would need further research by extending this analysis with the skin-in-the-game and more complex structure by increasing the number of clearing members, assets, and CCPs in the analysis.

The research's limitation is that we had only one CCP with four clearing members with small open positions. This could be the basis of future research examining this question using actual portfolios of several clearing members to see if the same phenomena are seen from the cross-guarantees perspective and the guarantee system's size.

We aim to extend our research to examine the same question on the whole guarantee system level, including the $\mathrm{CCP}^{\prime}$ 's contribution to the default fund and the skin-in-the-game.

Author Contributions: Conceptualization, K.V.; methodology, K.M.-S. and K.V.; formal analysis, M.F., K.M.-S., A.P. and K.V.; resources, M.F. and K.V.; data curation, K.V.; writing-original draft preparation, M.F., K.M.-S., A.P. and K.V.; writing-review and editing, M.F. and K.V.; visualization, A.P. and K.V.; supervision, K.V.; project administration, M.F. and K.V.; funding acquisition, K.V. All authors have read and agreed to the published version of the manuscript. 
Funding: This study was prepared in the framework of "From a Talent into a Young Researcher" No. EFOP-3.6.3.-VEKOP-16-2017-00007, a program supporting research careers.

Data Availability Statement: No new data were created or analyzed in this study. Data sharing does not apply to this article since the article uses simulated data.

Acknowledgments: We are grateful to KELER CCP for the professional support and consultation.

Conflicts of Interest: The authors declare no conflict of interest. The funders had no role in the design of the study; in the collection, analyses, or interpretation of data; in the writing of the manuscript, or in the decision to publish the results.

\section{References}

Baker, Colleen M. 2021. Clearinghouse Shareholders and "No Creditor Worse Off Than in Liquidation" Claims. Transactions: The Tennessee Journal Of Business Law 22: 335-53.

Banai, Ádám, Zsuzsanna Hosszú, Gyöngyi Körmendi, Sándor Sóvágó, and Róbert Szegedi. 2013. Stressztesztek a Magyar Nemzeti Bank Gyakorlatában, (Stress Tests in the Practice of the Central Bank of Hungary). MNB Working Paper 109. Available online: https: / / www.mnb.hu/letoltes/mt109-vegleges.pdf (accessed on 1 March 2018).

Barker, Russell, Andrew Dickinson, Alex Lipton, and Rajeev Virmani. 2016. Systemic Risks in CCP Networks. arXiv arXiv:1604.00254. Available online: http:/ / arxiv.org/abs /1604.00254 (accessed on 1 March 2018).

BCBS. 2009. Principles for Sound Stress Testing Practices and Supervision. Consultative Document. Available online: https://www.bis. org/publ/bcbs147.pdf (accessed on 1 March 2018).

Béli, Marcell, and Kata Váradi. 2016. Alapletét meghatározásának lehetséges módszertana [A possible methodology for determining initial margin]. Financial and Economic Review 16: 119-47.

Berlinger, Edina, Barbara Dömötör, and Ferenc Illés. 2018. Optimal Margin Requirement. Financial Research Letters 31. [CrossRef]

Berndsen, Ron. 2020. Five Fundamental Questions on Central Counterparties (SSRN Scholarly Paper ID 3709691). Social Science Research Network. [CrossRef]

Biais, Bruno, Florian Heider, and Marie Hoerova. 2012. Clearing, counterparty risk, and aggregate risk. IMF Economic Review 60: 193-222. [CrossRef]

Biais, Bruno, Florian Heider, and Marie Hoerova. 2016. Risk-sharing or Risk-taking? Counterparty Risk, Incentives and Margins. Journal of Finance 71: 1669-98.

Black, Fischer, and Myron Scholes. 1973. The pricing of Options and Corporate Liabilities. Journal of Political Economy 81: 637-54. [CrossRef]

Bo, Lijun, Yanchu Liu, and Tingting Zhang. 2021. Dynamic analysis of counterparty exposures and netting efficiency of central counterparty clearing. Quantitative Finance 21: 1187-206. [CrossRef]

Braithwaite, Jo, and David Murphy. 2016. Got to be Certain: The Legal Framework for CCP Default Management Processes. Financial Stability Paper No. 37. May. Available online: https://www.bankofengland.co.uk/-/media/boe/files/financial-stability-paper/ 2016/got-to-be-certain-the-legal-framework-for-ccp-default.pdf (accessed on 16 August 2021).

Campbell, Sean D., and Ivan Ivanov. 2016. Empirically Evaluating Systemic Risks in CCPs: The Case of Two CDS CCPs. Available online: https: / / ssrn.com/abstract=2841076 (accessed on 27 January 2020).

Canabarro, Eduardo. 2013. Stress testing design. Journal of Risk Management in Financial Institution 7: 52-61.

Capponi, Agostino, Jessie Jiaxu Wang, and Hongzhong Zhang. 2018. Designing Clearinghouse Default Funds (21 February 2018). Available online: http:/ / people.stern.nyu.edu/jhasbrou/SternMicroMtg/SternMicroMtg2018/Papers/designingCHdefaultfunds3 6.pdf (accessed on 27 January 2020).

Capponi, Agostino, Jessie Jiaxu Wang, and Hongzhong Zhang. 2020. A Theory of Collateral Requirements for Central Counterparties (February 2020). Available online: http:/ /www.public.asu.edu/ \{\}jwang391/pdfs/DF_main.pdf (accessed on 27 January 2020).

Central Bank of Hungary. 2019. A Magyar Nemzeti Bank 15/2019. (VII.9.) számú ajánlása a hitelkockázat méréséről, kezeléséről és kontrolljáról. Available online: https:/ / www.mnb.hu/letoltes/15-2019-hitelkockazat.pdf (accessed on 27 January 2020).

Chamorro-Courtland, Christian. 2011. The Trillion Dollar Question: Can a Central Bank Bail out a Central Counterparty Clearing House Which Is Too Big to Fail. Brooklyn Journal of Corporate Finance and Commercial Law 6: 433.

Cihák, Martin. 2007. Introduction to Applied Stress Testing. IMF Working Papers. WP/07/59. Available online: https://papers.ssrn.com/ sol3/papers.cfm?abstract_id=973989 (accessed on 1 March 2018).

CME Group. 2019. CME SPAN ${ }^{\circledR}$ Standard Portfolio Analysis of Risk ${ }^{\circledR}$. Available online: https://www.cmegroup.com/clearing/files/ span-methodology.pdf (accessed on 27 January 2020).

Cont, Rama. 2015. The end of the waterfall: Default resources of central counterparties. Journal of Risk Management in Financial Institutions 8: 365-89. [CrossRef]

Cumming, Fergus, and Joseph Noss. 2013. Assessing the Adequacy of CCPs' Default Resources. Bank of England Financial Stability Paper No. 26. Available online: https://www.bankofengland.co.uk/-/media/boe/files/financial-stability-paper/2013/assessingthe-adequacy-of-ccps-default-resources.pdf (accessed on 1 March 2019). 
Dodd-Frank Act. 2010. Dodd-Frank Wall Street Reform and Consumer Protection Act. Available online: https://www.congress.gov / 111/plaws/publ203/PLAW-111publ203.pdf (accessed on 1 March 2018).

Duffie, Darrell, Martin Scheicher, and Guillaume Vuillemey. 2015. Central clearing and collateral demand. Journal of Financial Economics 116: 237-56. [CrossRef]

EACH (European Association of CCP Clearing Houses). 2021. Carrots and Sticks: How the Skin in the Game Incentivizes CCPs to Perform Robust Risk Management. Working paper of Elena Tonetto and Rafael Plata Based on an Online Workshop on CCPs on 13 October 2020. Available online: https://www.eachccp.eu/wp-content/uploads/2021/01/EACH-Paper-Carrots-andsticks_How-the-skin-in-the-game-incentivises-CCPs-to-perform-robust-risk-management-January-2021.pdf (accessed on 27 June 2021).

EMIR. 2012. European Market Infrastructure Regulation: Regulation (EU) No 648/2012 of the European Parliament and of the Council of 4 July 2012 on the OTC Derivatives, Central Counterparties and Trade Repositories (EMIR-European Market Infrastructure Regulation). Available online: http:/ / eur-lex.europa.eu/legal-content/EN/TXT/PDF/?uri=CELEX:32012R0648\&from=EN (accessed on 17 July 2017).

ESMA. 2019. EU-Wide CCP Stress Test. ESMA. February. Available online: https://www.esma.europa.eu/press-news/esma-news / esma-launches-third-eu-wide-ccp-stress-test-exercise (accessed on 27 January 2020).

ESMA. 2020. EU-Wide CCP Stress Test. ESMA, July. Available online: https://www.esma.europa.eu/press-news/esma-news/esma\% E2\%80\%99s-third-eu-wide-ccp-stress-test-finds-system-resilient-shocks (accessed on 1 March 2021).

ESRB (European Systemic Risk Board). 2019. Adverse Scenario for the European Securities and Markets Authority's 2019 EU-Wide Central Counterparty Stress Test. Available online: https://www.esrb.europa.eu/mppa/stress/shared/pdf/esrb.stress_test190 403_EIOPA_insurance \{\}19eb9fb255.en.pdf (accessed on 27 January 2020).

Faruqui, Umar, Wenqian Huang, and Előd Takáts. 2018. Clearing risks in OTC derivatives markets: The CCP-bank nexus. BIS Quarterly Review, 73-90. Available online: https:/ / ssrn.com/abstract=3316367 (accessed on 27 January 2020).

Finance.yahoo.com. 2021a. Time Series of the DAX Index Prices for the Period of 12 January 1991-11 January 2021. Available online: https: / / finance.yahoo.com/quote/\%5EGDAXI/history?p=\%5EGDAXI (accessed on 12 January 2021).

Finance.yahoo.com. 2021b. Time series of the EUR/USD Currency Rate for the Period of 1 December 2003-11 January 2021. Available online: https: / finance.yahoo.com/quote/EURUSD\%3DX/history?p=EURUSD\%3DX (accessed on 12 January 2021).

Friesz, Melinda. 2020. The Financial System's Resilience is Everything, But at What Cost? Public Finance Quarterly 4: 472-84. [CrossRef]

Ghamami, Samim, and Paul Glasserman. 2017. Does OTC derivatives reform incentivize central clearing? Journal of Financial Intermediation 32: 76-87. [CrossRef]

Glasserman, Paul, and Qi Wu. 2017. Persistence and Procyclicality in Margin Requirements. Columbia Business School Research Paper, No. 17-34. Available online: https:/ / pubsonline.informs.org/doi/pdf/10.1287/mnsc.2017.2915?casa_token=mz0z7Hq-W3 gAAAAA\%3AMcXVG0K4ZwK3wwwen_3yIj4yejU_Ds_xsmzgg_AE6HiBVve64zKMqGLHBFdqaHpHl17Ou-Q58Vz\& (accessed on 18 October 2020).

Hilbers, Paul, and Matthew T. Jones. 2004. Stress Testing a Financial System. IMF Working Paper, WP/04/127. Available online: https: / / www.imf.org/external/pubs/ft/wp/2004/wp04127.pdf (accessed on 1 March 2019).

Huang, Wenqian, and Előd Takáts. 2020. Model Risk at Central Counterparties: Is Skin-in the-Game a Game Changer? BIS Working Papers, 866. Available online: https:/ / ssrn.com/abstract=3613194 (accessed on 27 January 2021). BIS Working Papers, 866.

Hull, J. C. 2015. Risk Management and Financial Institutions, 4th ed. Hoboken: John Wiley \& Sons Inc.

Jaidev, R. 2012. LCH. Clearnet splits default fund. Risk 25: 6.

Jorion, Philippe. 2007. Value at Risk: The New Benchmark for Managing Financial Risk. New York: McGraw-Hill, vol. 3.

KELER CCP. 2021. Available online: https:/ / english.kelerkszf.hu/Risk\%20Management/ (accessed on 27 January 2021).

King, Thomas B., Travis D. Nesmith, Anna L. Paulson, and Todd Prono. 2020. Central Clearing and Systemic Liquidity Risk. Finance and Economics Discussion Series 2020(009). Available online: https://www.econstor.eu/bitstream/10419/230378/1/1684704758.pdf (accessed on 1 March 2021).

Lopez, Claude, and Elham Saeidinezhad. 2017. Central Counterparties Help, But Do Not Assure Financial Stability. Munich Personal RePEc Archive, no. 80358. Available online: https:/ / mpra.ub.uni-muenchen.de/80358/ (accessed on 1 March 2019).

Madar, László. 2010. Stressztesztek használata anticiklikus tőkeszükséglet meghatározására, (Use of stress tests to determine anti-cyclical capital requirement). Financial and Economic Review 9: 431-44.

Mamon, Rogemar S. 2004. Three ways to solve for bond prices in the Vasicek model. Journal of Applied Mathematics and Decisions Sciences 8: 1-14. [CrossRef]

Markose, Sheri, Simone Giansante, and Ali Rais Shaghaghi. 2012. Too interconnected to fail, Financial networkof US CDS Market: Topological fragility and systemic risk. Journal of Economic Behavior and Organization 83: 627-46. [CrossRef]

McLaughlin, Dennis, and Ron Berndsen. 2021. Why Is a CCP Failure Very Unlikely? (CentER Discussion Paper; Vol. 2021-002). CentER, Center for Economic Research: Available online: https:/ / papers.ssrn.com/sol3/papers.cfm?abstract_id=3759694 (accessed on 10 April 2021).

McPartland, J., and R. Lewis. 2017. The Goldilock's problem: How to get incentives and default waterfall "just right". In Economic Perspective. Chicago: Federal Reserve Bank of Chicago, pp. 1-13.

Medvegyev, Péter, and János Száz. 2010. Meglepetések jellege a Pénzügyi piacokon (Properties of Surprises on the Financial Markets). Budapest: Nemzetközi Bankárképző Központ. 
Menkveld, Albert J., and Guillaume Vuillemey. 2021. The Economics of Central Clearing. Annual Review of Financial Economics 13. [CrossRef]

Murphy, David. 2013. OTC Derivatives: Bilateral Trading and Central Clearing. Hampshire: Palgrave Macmillan.

Murphy, David. 2017. I've got you under my skin: Large central counterparty financial resources and the incentives they create. Journal of Financial Market Infrastructures 5: 57-74. [CrossRef]

Murphy, David, and Paul Nahai-Williamson. 2014. Dear Prudence, Won't You Come out to Play? Approaches to the Analysis of CCP Default Fund Adequacy. Bank of England Financial Stability Papers No. 30. Available online: https://www.bankofengland.co.uk/-/ media/boe/files / financial-stability-paper / 2014/dear-prudence-wont-you-come-out-to-play-approaches-to-the-analysis-ofccp-default-fund-adequacy.pdf (accessed on 20 April 2018).

Murphy, David, Michalis Vasios, and Nick Vause. 2014. An Investigation into the Procyclicality of Risk-Based Initial Margin Models. Bank of England, Financial Stability Paper No. 28. Available online: https://www.bankofengland.co.uk/-/media/boe/files/financialstability-paper/2014/an-investigation-into-the-procyclicality-of-risk-based-initial-margin-models.pdf (accessed on 20 April 2018).

Murphy, David, Michalis Vasios, and Nick Vause. 2016. A Comparative Analysis of Tools to Limit the Procyclicality of Initial Margin Requirements. Bank of England Working Paper No. 597. Available online: https://www.bankofengland.co.uk/-/media/boe/files/ working-paper/2016/a-comparative-analysis-of-tools-to-limit-the-procyclicality-of-initial-margin-requirements.pdf (accessed on 20 April 2018).

Nahai-Williamson, Paul, Tomohiro Ota, Michalis Vital, and Anne Wetherilt. 2013. Central Counterparties and their Financial Resources-A Numerical Approach. Bank of England Financial Stability Paper No. 19. Available online: https://www.bankofengland.co.uk/-/media/ boe/files/financial-stability-paper/2013/central-counterparties-and-their-financial-resources-a-numerical-approach.pdf (accessed on 20 April 2018).

Novick, Barbara, Richie Prager, Joanna Cound, Joanne Medero, Supurna VedBrat, and Stuart Anderson. 2014. Central Clearing Counterparties and Too Big to Fail. This Paper Is Part of a Series of BlackRock Public Policy ViewPoints. April. Available online: https:/ / www.blackrock.com/corporate/literature/whitepaper/viewpoint-ccp-tbtf-april-2014.pdf (accessed on 18 October 2018).

Paddrik, Mark, and H. Payton Young. 2017. How Safe Are Central Couterparties in Derivative Markets? Discussion Paper. Oxford: University of Oxford.

Paddrik, Mark, and H. Payton Young. 2021. How safe are central counterparties in credit default swap markets? Mathematics and Financial Economics 15: 41-57. [CrossRef]

Parkinson, Patrick M. 2014. CCP Liquidity Risk Management and Related Failure Management Issues, Federal Reserve Bank of Chicago. Available online: https://www.chicagofed.org/ \{\}/media/others/events/2014/annual-over-the-counter-derivativessymposium/parkinson-ccp-derivatives-over-the-counter-2014-pdf.pdf (accessed on 18 October 2018).

Platt, Colin, Péter Csóka, and Massimo Morini. 2017. Implementing Derivatives Clearing on Distributed Ledger Technology Platforms. R3 Reports. Available online: https://www.r3.com/wp-content/uploads/2017/11/implementing-derivatives-clearing_R3_.pdf (accessed on 1 March 2020).

Poce, Giulia, Giulio Cimini, Andrea Gabrielli, Andrea Zaccaria, Giuditta Baldacci, Marco Polito, and Silvia Sabatini. 2018. What do central counterparties default funds really cover? A network-based stress test answer. Journal of Network Theory in Finance 4: 43-57. [CrossRef]

RTS. 2013. Technical Standard: Commission Delegated Regulation (EU) 153/2013 of 19 December 2012 Supplementing Regulation (EU) No 648/2012 of the European Parliament and of the Council with Regard to Regulatory Technical Standards on Requirements for Central Counterparties. Available online: http:/ / eur-lex.europa.eu/LexUriServ/LexUriServ.do?uri=OJ:L:2013:052:0041:0074:EN: PDF (accessed on 17 July 2017).

Schinasi, Garry J. 2004. Defining Financial Stability. IMF Working Paper 2004. Available online: https://www.elibrary.imf.org/view / journals /001/2004/187/article-A001-en.xml (accessed on 1 March 2018).

Szanyi, Csilla, Melinda Szodorai, and Kata Váradi. 2018. Supplementation of the regulation of anti-cyclical margin measures of clearing activities. Paper presented at the 31st European Conference on Modelling and Simulation, Wilhelmshaven, Germany, May 22-25; pp. $74-80$.

Tywoniuk, Magdalena. 2020. CDS Central Counterparty Clearing Default Measures: Road to Recovery or Invitation to Predation? SSRN Electronic Journal. [CrossRef]

US CFTC. 2016. Supervisory Stress Test of Clearinghouses. A Report by Staff of US Commodity Futures Trading Commission. Available online: https://www.cftc.gov/sites/default/files/idc/groups/public/@newsroom/documents/file/cftcstresstest111516.pdf (accessed on 1 March 2018).

Vasicek, Oldrich. 1977. An equilibrium characterization of the term structure. Journal of Financial Economics 5: 177-88. [CrossRef] 